\title{
CIVIL SOCIETY AND PUBLIC CONTROL: A SCIENTIFIC DISCUSSION ON THE INTERDEPENDENCE OF CONCEPTS
}

\section{ГРОМАДЯНСЬКЕ СУСПІЛЬСТВО ТА ГРОМАДСЬКИЙ КОНТРОЛЬ: НАУКОВА ДИСКУСІЯ ПРО ВЗАЄМООБУМОВЛЕНІСТЬ ПОНЯТЬ}

\author{
Iliya Skvirskyi \\ Doctor of Law, Associate Professor, \\ Professor of the Department of Administrative and Customs Law, \\ University of Customs and Finance \\ ORCID: 0000-0002-0910-0636
}

Сквірський I. 0.

Доктор юридичних наук, доцент, професор кафедри адміністративного та митного права Університет митної справи та фрінансів

In the article, based on the analysis of doctrinal sources of domestic and foreign legal scholars, an attempt is made to establish the relationship between the concepts of civil society and public control. To solve this problem, the author analyzes the content and main features of these categories, as well as their relationship with the term rule of law. emphasize that civil society and public control are interrelated and complementary concepts. The development of civil society inevitably improves the efficiency of the organization and implementation of public control, which is its necessary tool that can neutralize illegal decisions and actions of public authorities. As for the legal provision of public control, it should be emphasized that the latter, although it has a certain normative basis in the form of separate articles of the Constitution of Ukraine, the Law of Ukraine "On Access to Public Information", the Law of Ukraine "On Citizens' Appeals", the Law Ukraine "On democratic civilian control over the military organization and law enforcement agencies of the state", but deprived of a consolidating principle, as the Law of Ukraine "On Public Control". Civil society and public control are interrelated and complementary concepts. Key words: civil society, control, social control, the rule of law.

В статье, на основании анализа доктринальных источников отечественных и зарубежных ученых-юристов, сделана попытка установления соотнощения понятий гражданское общество и общественный контроль. Для решения этой задачи автором проанализировано содержание и основные черты названных категорий, а также установлена их взаимосвязь с термином правовое государство. подчеркнем, что гражданское общество и общественный контроль являются взаимосвязанными понятиями, которые дополняют друг друга. Развитие гражданского общества предполагает непременное улучшение эфрфективности организации и осуществления общественного контроля, который является необходимым инструментом, способным нейтрализовать неправовые решения и действия публичной власти. Ключевые слова: гражданское общество, контроль, общественный контроль, правовое государство.

У статmі, на підставі аналізу доктринальних джерел вітчизняних та зарубіжних вчених-правників, зроблено спробу встановлення співвідношення понять громадянське суспільство та громадський контроль. Для вирішення цього завдання автором проаналізовано зміст та основні риси названих категорій, а також встановлений їх взаємозв'язок з терміном правова держава та верховенство права. Наголошено на тому, що громадянське суспільство та громадський контроль є взаємопов'язаними поняттями, які доповнюють одне одного. Відзначено, що проблеми громадянського суспільства почали досліджувати вітчизняними науковиями лише після здобуття Україною незалежності та проголошення ії демократичною, соціально-правовою державою, яка визнає (утверджує) та забезпечує права, свободи та законні інтереси людини і громадянина. Визначено, що вітчизняні вчені у своїй роботі вдаються до досліджень, які знаходяться на стику різних наук: права і соціології, права і фрілософрії, права і політології тощо. Обгрунтовано, що такий напрям наукових досліджень носить міждисциплінарний характер, висновки та пропозиції, сформульовані за його результатами, здатні найбільш повно та всебічно відобразити сучасний стан та перспективи суспільних відносин у нашій державі. Акцентовано, що громадянське суспільство є теоретичною конструкцією, певним ідеалом, який передбачає певну сукупність відносин соціального, економічного, політико-правового характеру, спрямованих на встановлення та забезпечення прав, свобод і законних інтересів осіб, які проживають у певній державі. Виявлено, що істотним елементом громадянського суспільства є верховенство права, яке, з одного боку, забезпечує лише досяжні передумови для формування та розвитку громадянського суспільства (юридичні засоби забезпечують визнання, захист і захист прав людини), а також з іншого боку - антитеза громадянського суспільства, існування якого, однак, є обов'язковим, оскільки без нього таке суспільство може стати 
деспотом певних соціальних груп чи індивідів. Підкреслено, що громадянське суспільство та громадський контроль є взаємопов'язаними та взаємодоповнювальними поняттями. Розвиток громадянського суспільства передбачає неодмінне покращення ефективності організації та здійснення громадського контролю, який є його необхідним інструментом, здатним нейтралізувати неправові рішення та дії публічної влади. Ключові слова: громадянське суспільство, контроль, громадський контроль, правова держава.

Statement of the problem in general and its connection with important scientific or practical tasks. An analysis of the modern scientific literature on administrative law shows that more and more often domestic scholars resort to research in their work, which is at the intersection of different sciences: law and sociology, law and philosophy, law and political science and more. Such a direction of scientific research should be welcomed and supported in every way, because interdisciplinary conclusions and proposals formulated based on its results, in our opinion, are able to most fully and comprehensively reflect the current state and prospects of social relations in our country. They are also extremely valuable for law-making entities, which in the process of their activity should operate only with those data and indicators that are as consistent as possible with the needs and expectations of society. Only under this condition can we hope for the development and adoption of effective legal acts

An analysis of recent research and publications in which the solution to this problem has been initiated and on which the author relies. Such research includes those that raise the question of the relationship between law and civil society, the administrative and legal support of public control in Ukraine. V. Averyanov, V. Garashchuk, O. Kresin, O. Petryshyn, P. Rabinovych and others devoted their works to this topic at different times. However, the question of the relationship, interdependence and interdependence of civil society and public control remained out of the attention of these authors, which, in fact, is the purpose of this article. To achieve it, we plan to solve the following tasks: clarifying the content and main features of civil society and public control; establishing their relationship with the concept of the rule of law; identification of factors that hinder the formation of civil society in Ukraine and reduce the effectiveness of public control.

Formulation of the goals of the article (task statement) - an attempt is made to establish the relationship between the concepts of civil society and public control. To solve this problem, the author analyzes the content and main features of these categories, as well as their relationship with the term rule of law.

Presentation of the main research material. The problems of civil society began to be studied by domestic scholars only after Ukraine gained independence and proclaimed it a democratic, social and legal state, which recognizes (affirms) and ensures the rights, freedoms and legitimate interests of man and citizen. In view of this, we can agree with the opinion of P. Rabinovych, who believes that the interpretation of civil society should be carried out through the prism of human rights. The author explains this approach by the fact that: first, society itself (or rather - the accumulated material, social, spiritual and other resources) is the main source of meeting vital human needs, "reservoir» of the formation and implementation of human capabilities, which, in fact, constitute the law; secondly, the real individual chances of a person's access to these resources, the use of the accumulated benefits of society depend on which social group a person belongs to, what position such a group occupies in society, what are the relationships of different groups among themselves and between them and the state; thirdly, human rights, their feasibility are directly determined by the extent to which they are approved and «distributed» by the bearers of public ( «public») power - primarily by the state: in the interests of everyone or primarily in the interests of a certain part of society [1].

It should be noted that the conclusions made quite clearly are confirmed by domestic historical experience, which shows that in Soviet times, which were characterized by neglect of the rights and freedoms of citizens, civil society did not exist. This was mainly due to the fact that the citizens of the USSR were not endowed primarily with subjective public rights, is they did not have the opportunity to demand that the state behave properly, as well as create opportunities to exercise their rights and freedoms at the regulatory level. This task in democratic, social and legal states is performed at the expense of administrative law, designed, as is well known, to protect individuals from the arbitrariness of state power, to guarantee and ensure the exercise of their subjective public rights. [2, p. 129]. In view of this, it can be concluded that civil society can be formed and developed with two main prerequisites: first, the recognition of the rights, freedoms and legitimate interests of individuals and, second, the existence of democratically oriented administrative law designed to create private individuals need opportunities to exercise their powers and, above all, in the relationship of the latter with the state. By the way, this opinion can be confirmed by reference to Art. 3 of the Constitution of Ukraine, which states that the establishment and protection of human rights and freedoms is the main duty of the state [3]. The main meaning of this, as rightly emphasized in the literature, means the subordination of all state institutions to the needs of realization and protection of human rights, the assertion of their priority over 
all other values of a democratic, social, legal state $[4$, p. 236]. Thus, to some extent, civil society can be defined as a social formation opposite to the state, which encourages the latter to create the conditions necessary for the full development and existence of members of such a society. In other words, civil society is a kind of counterweight to the state, which, however, focuses on mutually beneficial and conflictfree existence with it. However, the opinion does not mean that civil society exists only to demand something from the state. On the contrary, it focuses, among other things, on cooperation with public authorities, on providing them with the necessary assistance and assistance in the implementation of the tasks assigned to them.

This form of relationship between civil society and the state, in turn, requires the formation of the institution of their corresponding rights and responsibilities, because otherwise members of civil society will be seen as subordinate entities, rather than full participants in the relationship. It should be noted that now at the constitutional level the necessary foundations for the formation of this institution have been laid, which is manifested, in particular, in Art. 3 of the Basic Law, which states that the state is responsible to the person for its activities, as well as in Art. 56, which guarantees individuals compensation for damage caused by illegal actions or decisions of officials (officials) of public authorities and local governments. However, at the same time, this cannot be stopped, because without the introduction of real institutions of state responsibility to civil society and its members, these provisions will quickly turn into legal fiction. In this regard, in our opinion, it is extremely necessary to develop and adopt the Law of Ukraine «On State Liability for Damage Caused by Its Officials in the Performance of Official Duties.» The absence of this legislation, unfortunately, allows us to state that in our country the principle of mutual responsibility of the state and the individual has not yet been implemented, which, of course, has a negative impact on the formation of civil society in Ukraine.

The formation of civil society, as well as the efforts of politicians and statesmen to facilitate this process, involves clarifying its most defining features, around which, in fact, the so-called "construction» should take place. Currently, a number of opinions on this subject have been expressed in the literature. Thus, P. Rabinovych believes that such signs are the following:

1) recognition of a person with his needs and interests, rights and freedoms as the central subject of society. According to the scientist, this practically means that in solving any social problems, affairs, issues it is the person, his existence and development who is given an absolute, indisputable priority. Human rights are recognized as a universal limit that no one is allowed to cross: no other people, no public associations, organizations, much less the state;

2) turning people into owners. «A person deprived of real», personalized "ownership of the means of production becomes a person» tied «to economic (proletariat), and once - and non-economic (slave, serfdom) dependence on another person - the owner. The smaller the share of such dependent people in the population, the wider the circle of free people who choose their strategy, way and style of life only of their own free will (and not due to state pressure, administrative or corporate coercion).;

3) existence of a market, socially oriented economy. This provides the most favorable conditions for the exercise of economic and social human rights, as well as creates and accumulates material resources necessary, above all, to ensure the existence of the most vulnerable groups.;

4) the existence of a pluralistic self-regulatory society of politically active citizens. The level of complexity of the social structure, the degree of its pluralism is one of the indicators of the development of society [1].

D. Kerimov defines the characteristic features of civil society in a slightly different way, emphasizing that the latter:

- is formed from a set of persons, different nations and nationalities, united in a single community within the relevant territory;

- consists of a set of voluntary public organizations and movements that serve the individual and common good;

- organizes the realization of the interests of all for the sake of normal functioning and progressive social development;

- ensures the freedom, independence and equality of all its members on the basis of a broad democracy [5].

V. Gorbatenko offers his version of the features of civil society, noting that the latter occurs in the case of:

- priority of private property and related interests of owners;

- the presence of a highly developed «middle class», which cements the state and public life;

- a high level of vital and creative opportunities for self-realization of the individual in all spheres of public life;

- the functioning of a significant number of sociopolitical organizations that reflect the interests of various social groups;

- continuous development and affirmation of the public through the exchange of complementary qualities on the principle of «political society and political citizenship» [6].

In view of the above, the question arises as to which of the above concepts of the main features of civil society is more balanced and as close as 
possible to the needs of today? Answering the question, we note that the list of features of civil society cannot be frozen, because within the latter there are constant transformational transformations, which, accordingly, require a revision of its defining features. In addition, the state and prospects of civil society development also depend on the historical, cultural and other features of a nation. Therefore, it is natural that some features of civil society may be replaced by others over time. But all of them, in our opinion, will be united by the main goal of the existence of civil society - to create conditions for the comprehensive and full development of the individual within a democratic, social and legal state.

Civil society is a theoretical construction, a certain ideal, which provides for a certain set of relations of social, economic, political and legal nature, aimed at establishing and ensuring the rights, freedoms and legitimate interests of individuals living in a particular state. In our opinion, an essential element of civil society is the rule of law, which, on the one hand, provides only achievable prerequisites for the formation and development of civil society (legal means provides recognition, protection and defense of human rights), and on the other hand the antithesis of civil society, the existence of which, however, is mandatory, because without it such a society can become a despot of certain social groups or individuals. In fact, civil society and the rule of law are a system of checks and balances that prevent their degeneration and decline, contributing, as a result, to their constructive coexistence.

The above, in fact, explains the existence of both the state and civil society of certain tools to influence their counterparties. It is clear that the state has greater opportunities in this area, while civil society can achieve, in fact, only public control over the actions and decisions of public authorities. However, in view of the above, it becomes clear that public control must be as effective and efficient as possible, because otherwise civil society will be deprived of the opportunity to influence the state, to correct its illegal and anti-social behavior.

Thus, we can draw an intermediate conclusion that public control is an element of civil society designed to balance the interests of the latter and the state. In this regard, we can support $O$. Sushinsky, who rightly emphasizes that the presence of such control is a systemic feature of the institutional structure of civil society, the main factor in community selforganization [7, p. 14]. At the same time, it should be understood that the effectiveness of public control largely depends on the desire and willingness of the state to implement it, give it a legal definition, to establish implementation procedures.

An analysis of the practice of public control in Ukraine allows us to conclude that it is gradually becoming clear, and its consequences (results) bind public authorities in its decisions and actions. The most typical example of this is the events that took place in 2004 and were related to the review of the results of the presidential election at the request of the political opposition. This example, in our opinion, shows that public control is indeed an effective way of influencing public authorities, which, however, requires further improvement. In this case, we are talking about the fact that today in Ukraine there are many factors that prevent the transformation of the latter into a truly effective tool for civil society. The main among them are, in our opinion, problems of theoretical and legal nature.

In the first case, it is a question of insufficient elaboration of the very concept of public control in the domestic scientific literature. Thus, acquaintance with the relevant scientific works shows that the current definitions of public control do not fully reflect the purpose of the latter in civil society. For example, $S$. Shestak understands the latter as the control of citizens and their voluntary associations, aimed at ensuring the legality and transparency of the state mechanism, the development of permanent and effective relations between the state and the population [8]. However, in our opinion, the main emphasis in defining public control should be made not on ensuring legality in the activities of state institutions, as this task is performed by relevant public entities, but on encouraging the latter to fully ensure the rights, freedoms and legitimate interests of individuals. . The issue of forms of public control, which by some authors are reduced to: participation of public representatives in the work of commissions and committees of state bodies, also remains unresolved in science; participation of the representative of public control in expert-consultative activity for the purpose of maintenance of high quality of the bills, regulations and other documents prepared by state bodies; coordination of decisions of public authorities on personnel issues [9]. However, in reality the forms of public control are not limited to the above. To confirm this, it will suffice to mention only public hearings, information requests, the work of public inspectors, and so on.

As for the legal provision of public control, it should be emphasized that the latter, although it has a certain normative basis in the form of separate articles of the Constitution of Ukraine, the Law of Ukraine "On Access to Public Information», the Law of Ukraine "On Citizens' Appeals», the Law Ukraine "On democratic civilian control over the military organization and law enforcement agencies of the state», but deprived of a consolidating principle, as the Law of Ukraine «On Public Control».

Conclusion. So, to sum up, we emphasize that civil society and public control are interrelated and complementary concepts. The development of civil society inevitably improves the efficiency of the organization and implementation of public control, which is its necessary tool that can neutralize illegal decisions and actions of public authorities. 


\section{REFERENCES:}

1. Rabinovych, P. (1996). Civil society and the rule of law (general theoretical considerations). Ukrainian law.Vol. 3. p. 22-34. (in Ukrainian).

2. Elistratov, A.I. (1917). Basic principles of administrative law. Treatise. Moscow. (In Russian)

3. Constitution of Ukraine (1996). Information of the Verkhovna Rada of Ukraine. Vol 30. (in Ukrainian).

4. Averianov, V.B. (2007). Public administration: European standards, experience and administrative law. Treatise. Kyiv. (in Ukrainian).

5. Kerimov, D.A. (2004). Civil society and the rule of law. Law and education. Vol. 1. p. 5-16.

6. Gorbatenko, V.P. (2002). Strategic guidelines for the interaction of the state and civil society. Bulletin of the State Academy of Management of Culture and Arts. Vol. 3. p. 127-134.

7. Sushinsky, O.I. (2002). Control in the sphere of public power: theoretical-methodological and organizationallegal aspects. Treatise. Lviv. (in Ukrainian).

8. Shestak, S.V. (2006). Civil, civil and public control: to the definition of concepts. Bulletin of Kharkiv National University of Internal Affairs. Vol. 35. p. 36-43.

9. Barabash, Yu. Pavshuk, K. (2010). The essence of public control in Ukraine. Law Journal of Donetsk University. Vol 1. p. 168-175.

\section{БІБЛІОГРАФІЧНИЙ СПИСОК:}

1. Рабінович П. Громадянське суспільство і правова держава (загальнотеоретичні міркування). Українське право. 1996. № 3. С. 22-34.

2. Елистратов А. И. Основные начала административного права. 2-е изд. М., 1917. 294 с.

3. Конституція України. Відомості Верховної Ради України. 1996. № 30. Ст. 141.

4. Державне управління: Європейські стандарти, досвід та адміністративне право [В. Б. Авер'янов, В. А. Дерець, А. М. Школик та ін.]; за заг. ред. В. Б. Авер'янова. К. : Юстініан, 2007. 288 с.

5. Керимов Д. А. Гражданское общество и правовое государство. Право и образование. 2004. № 1. С. 5-16.

6. Горбатенко В. П. Стратегічні орієнтири взаємодії держави і громадянського суспільства. Вісник державної академії керівних кадрів культури і мистецтв. 2002. № 3. С. 127-134.

7. Сушинський О. І. Контроль у сфері публічної влади: теоретико-методологічні та організаційно-правові аспекти. Монографрія. Львів, 2002. 224 с.

8. Шестак С. В. Цивільний, громадянський та громадський контроль: до визначення понять. Вісник Харківського національного університету внутрішніх справ. 2006. № 35. С. 36-43.

9. Барабаш Ю. Павшук К. Сутність громадського контролю в Україні. Правничий часопис Донецького універсuтemy. 2010. № 1. C. 168-175. 